\title{
Relieving road congestion through motorway concessions in Moscow
}

\author{
S. Carpintero ${ }^{1}$, G. Camos Daurella ${ }^{2}$ \& R. Barcham ${ }^{3}$ \\ ${ }^{1}$ Polytechnic University of Madrid, Spain \\ ${ }^{2} M S$ Civil Engineer (UPC/ENPC), Spain/France \\ ${ }^{3}$ Norbridge Inc., USA
}

\begin{abstract}
Russia has a well-developed and powerful transportation system. However, the entire transport infrastructure was designed to meet the needs of a closed and centralized economy. It has become clear that the current road network does not fulfill Russia's social and economic needs. The growth of Russia's road network has fallen far behind motorization rates and the growing demand for road transportation. This gap is a result of the low level of investment in road infrastructure, especially during the last decade. The lack of an adequate stock of roads is particularly evident in Moscow, leading to extremely high traffic congestion, with adverse consequences in terms of wasted time, air pollution, noise, climatic effects, etc.

Increased investment in road infrastructure is necessary to reduce Moscow's road congestion. To this end, in addition to increasing public investment, it would be helpful to involve the private sector by means of public-private partnerships (PPP).

This paper analyses the issues surrounding road concessions and the challenges and difficulties of using a PPP model in Russia. First, the study analyses data on the evolution of the road network and of transport demand in Russia over the last decade. These data illustrate the difficulties of maintaining the road network and of responding to the growing transport demand. Then the paper reviews the challenges of PPP projects aimed at improving the road network, focusing on two recently granted motorway concessions near Moscow. Finally, prospects for further development of public-private partnerships to relieve road congestion in the Russian capital are explored.
\end{abstract}

Keywords: transport, infrastructure, Russia, concession. 


\section{Introduction}

This paper examines the evolution of investment in the road infrastructure of the Russian Federation over the last two decades. The principal source used is official data published by the Federal State Statistics Service, particularly the latest available issues of the publications of Transport in Russia (2007), Statistical Yearbook of Russia (2007) and Russia in figures (2008) [1-3] Analysis of these data leads to the conclusion that the stock of road infrastructure has barely increased over this period of time.

The study also analyses the evolution of demand for transport by road. Due to the lack of available data regarding private cars, analysis focuses on freight transportation using data published by the Federal State Statistics Service and by the International Transport Forum (OECD). After a significant decrease between 1990 and 1999, freight transportation by road started to increase significantly through 2009. In addition, recent studies such as Filina [4] show a spectacular increase in the vehicle fleet over the last decade in the Russian Federation. This can be taken as a proxy for growth in road transport demand. Furthermore, according to senior Russian government officials, this growth will continue in the future.

Traffic congestion is the result of a combination of a low investment in the road network and a considerable increase of transport demand. Congestion is prevalent in Moscow, with dramatic consequences for wasted time and environmental pollution. Due to limited data on these issues, this paper presents public statements by senior Russian government officials which underline the severity of these problems.

One possible means of reducing such congestion problems would be provision of more urban motorways in the city of Moscow by means of public private partnerships (PPP). In summer 2009 two motorway concessions were awarded for which the tender process had started two years ago. These two bidding processes are briefly discussed in this paper thanks to the authors' direct knowledge of the projects.

However, in order to successfully use PPPs to increase the number of urban motorways in Moscow and its surroundings, several conditions must be met. These conditions are identified from the authors' experience and from recent publications on the matter.

\section{The growth of Russia's road network has fallen far behind motorization rates and the growing demand for road transportation}

\subsection{Development of road transportation in Russia}

Over the past several years, road transportation demand and the vehicle fleet have increased considerably. Data on road transportation are very poor in Russia, with data available for bus transportation only. However, there are more reliable data for the vehicle fleet. These show that the vehicle fleet has radically 
Table 1: $\quad$ Road vehicles (thousand units).

\begin{tabular}{|c|c|c|c|c|c|c|c|c|}
\hline & 1995 & 2000 & 2001 & 2002 & 2003 & 2004 & 2005 & 2006 \\
\hline $\begin{array}{l}\text { Lorries, total of } \\
\text { which }\end{array}$ & 2,937 & 4,122 & 4,218 & 4,331 & 4,363 & 4,470 & 4,564 & 4,592 \\
\hline - public & 319 & 128 & 110 & 89 & 71 & 57 & 50 & 44 \\
\hline - private & 798 & 1.548 & 1.678 & 1.888 & 1.966 & 2.118 & 2.265 & 2375 \\
\hline Buses, total of which & 513 & 624 & 648 & 687 & 715 & 747 & 778 & 807 \\
\hline - public & 128 & 109 & 197 & 101 & 93 & 86 & 79 & 72 \\
\hline - private & & 183 & 208 & 246 & 268 & 299 & 331 & 361 \\
\hline $\begin{array}{l}\text { Passenger cars, total } \\
\text { of which }\end{array}$ & 14,195 & 20,247 & 21,152 & 22,342 & 23,271 & 24,091 & 25,461 & 26,656 \\
\hline - private cars & 13,668 & 19,061 & 19,971 & 21,088 & 22,046 & 22,812 & 24,088 & 25,235 \\
\hline
\end{tabular}

Source: Transport in Russia 2007, Federal State Statistics Service [1].

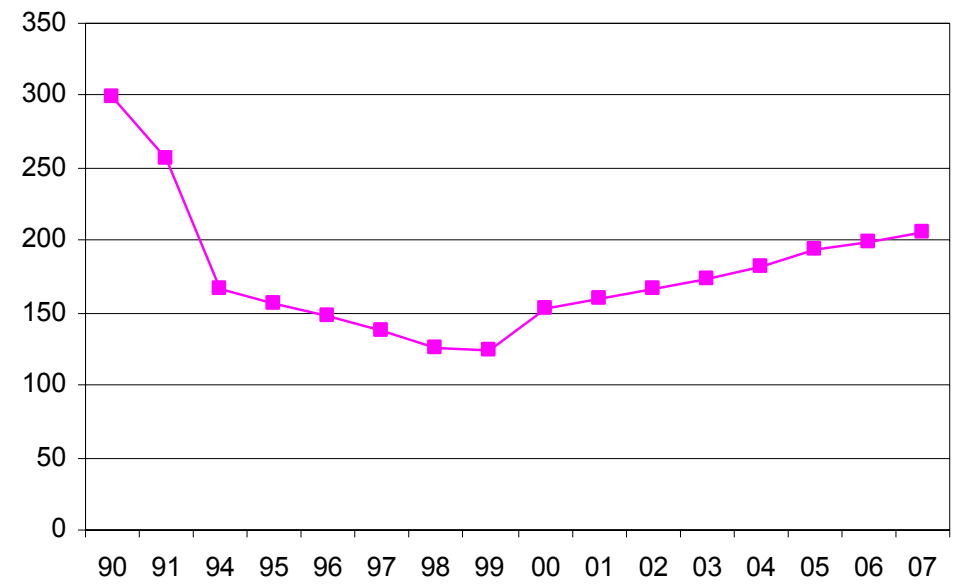

Source: International Transport Forum (OECD), Russia in figures 2008 and Statistical Yearbook of Russia 2007 (Federal State Statistics Service) [2. 3, 13].

Figure 1: Road freight transport turnover in Russia, 1990-2007 (billions tn$\mathrm{km})$.

increased over the last 10 to 15 years. According to the Federal State Statistic Service, between 1995 and 2005 there was an increase of 55 percent in the number of trucks, 52 percent of the number of buses and 80 percent in the number of cars (fig. 1). By 2007 Russians owned on average 200 cars per 1000 inhabitants [4]. This explosion in the size of the vehicle fleet may be explained by the small initial size of the fleet in 1995 relative to Western Europe, and by the increase in buying power of the population. As a result, private transportation by car has quickly replaced bus transportation, which has decreased by over 50 percent in terms of passenger-km between 1990 and 2007. 
In terms of tonne-km, freight transportation by road increased by 60 percent from minimum levels in 1999 to 2007, as shown in fig. 1. Between 1990 and 1995 the number of tonne-km had decreased by 50 percent due to the economic collapse of the country.

\subsection{The need for a higher stock of road infrastructure}

The spectacular increase of the vehicle fleet, together with the increase in demand for freight transportation by road, point out the need for a greater stock of road infrastructure. The reality is that the current road network cannot meet the existing transport demand which has expanded in tandem with the growth of the economy [5].

Considering future growth predictions, this need is even clearer. The number of cars per 1,000 inhabitants is expected to reach 450 in 2015 and 750 in 2025 [6]. The most significant growth is expected in large urban areas, in Western Russia and in the main corridors, and also in links with the borders of the European Union. The lowest growth is expected in the agricultural areas of Central Asia and Siberia [5].

It is estimated that road transportation will increase by 50 percent in the next 20 years, with most of the growth concentrated in the corridors between the EU and the large cities of the European Russia [5]. Additionally, as Russia becomes more and more adapted to the market economy, the size of the average transported freight will decrease while the diversity of origins and destinations will increase [5].

Currently energy exports account for 30 percent of Russia's total exports, while manufactured goods account for less than 10 percent; improving transport infrastructure is key in order to increase exports of non-energy products [5].

There is a clear need for better infrastructure to stimulate international trade. According to Eijbergen et al. [5], Western Russia needs to improve road and railway connections with the EU, while Eastern Russia needs to improve connections with China and Korea. The modernization program of the Russian transport system (2002-2010) predicts that road network length will increase in length to 670,000 kilometers and that motorways of four or more lanes will increase from 4,300 kilometers to 8,000 kilometers [7].

\subsection{Unsatisfactory stock of road infrastructure}

Despite the evidence of the need for more infrastructure, the stock of road infrastructure has barely increased over the last decade. Between 1990 and 2000 there was some investment in roads despite the overall weakness of the economy. Investment in transport infrastructure decreased between 2000 and 2005, both as a percentage of GDP and in absolute terms [5]. In 2006 and 2007 there was also some investment by local governments, as shown in fig. 2 .

There is a clear inequality between development of the road network in the east and in the west of the country (Filina [4]). As shown on Table 2, densities of the road network are much higher in Central and Western Russia than in Eastern Russia. 


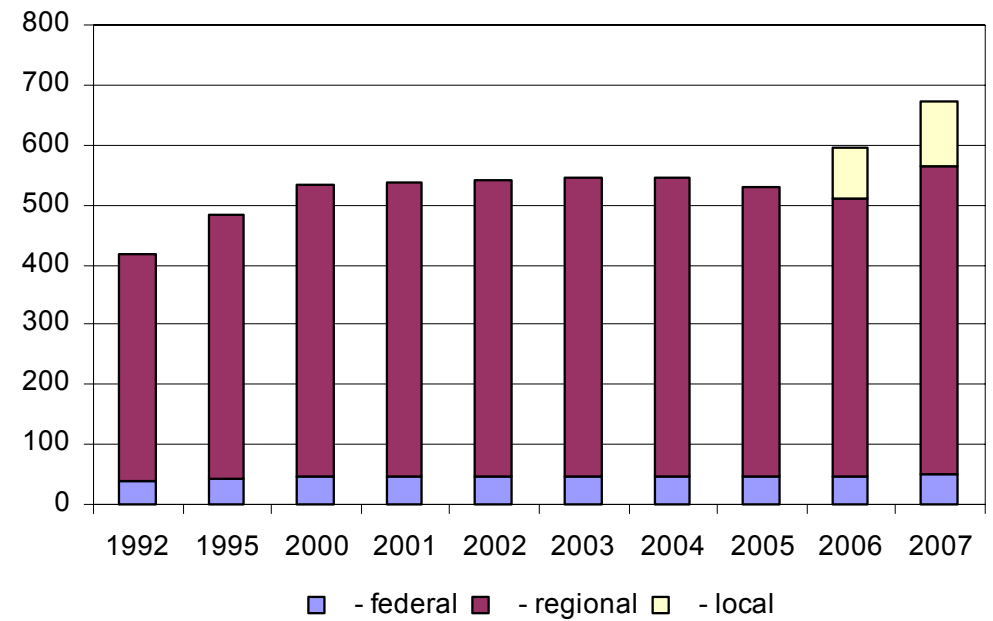

Source: Transport in Russia 2007 and Statistical Yearbook of Russia 2007 (Federal State Statistics Service) [1, 2].

Figure 2: $\quad$ Length of paved roads (thousands $\mathrm{km}$ ).

Differences in road density between Russia and Europe are significant. Motorway density in Russia is $32 \mathrm{~km} / 1.000 \mathrm{~km}^{2}$ whereas in Europe it ranges between 231 and $1085 \mathrm{~km} / 1.000 \mathrm{~km}^{2}$ [4].

Demand in major Russian corridors significantly higher than the available capacity. For example, the corridors connecting Moscow with the EU border, or the Black Sea with the Caspian Sea, have a capacity of 500 vehicles/day. However, they currently experience a demand of over 15,000 vehicles/day, representing an obstacle to the economic and social development of the regions they are connecting [5]. In addition, there is no North-South corridor linking the Arctic ports with the Baltic, Caspian or Black Sea ports [7].

Table 2: $\quad$ Density of network of public paved roads by regions ( $\mathrm{km}$ of roads per 1,000 square $\mathrm{km})$.

\begin{tabular}{ccccccccc}
\hline Federal District & 1995 & 2000 & 2001 & 2002 & 2003 & 2004 & 2005 & 2006 \\
\hline Central & 169 & 184 & 185 & 186 & 187 & 188 & 179 & 206 \\
Northwestern & 37 & 40 & 40 & 40 & 40 & 40 & 40 & 43 \\
Southern & 99 & 107 & 108 & 110 & 110 & 110 & 97 & 135 \\
Volga & 105 & 121 & 122 & 123 & 124 & 125 & 126 & 130 \\
Urals & 17 & 19 & 20 & 20 & 20 & 20 & 21 & 21 \\
Siberian & 16 & 17 & 18 & 18 & 18 & 18 & 17 & 20 \\
Far Eastern & 5 & 5.5 & 5.4 & 5.3 & 5.4 & 5.4 & 5.4 & 5.9 \\
Average Russian & & & & & & & & \\
Federation & 28.3 & 31.2 & 31.4 & 31.7 & 31.9 & 32 & 31 & 34.9 \\
\hline
\end{tabular}

Source: Transport in Russia 2007, Federal State Statistics Service [1]. 


\section{The consequences and costs of traffic congestion in Moscow}

The lack of sufficient capacity generates congestion on the existing road network throughout Russia. This phenomenon is particularly prominent in Moscow, with dramatic consequences in terms of loss of time, environmental pollution and traffic crashes.

\subsection{The low capacity of the existing road network around Moscow}

Around 80 percent of Moscow's roads are running above capacity. The quantity of cars is growing rapidly. The shortage in the network of arterial streets is of about $350-400 \mathrm{~km}$, decreasing average traffic speeds to $5-10 \mathrm{~km} / \mathrm{h}$. At peak travel during rush hour, 400,000 cars crowd the streets. The average driver spends 11 hours per week in traffic jams, amounting to 40-45 hours monthly. Workdays typically see about 800 traffic jams involving hundreds of thousands of cars [8].

In addition, forecasts suggest future deterioration. Population in Moscow and the surrounding region is expected to increase over the next 20 years from the current 17 million to a total of 20 million. Of these, 12 million will be in Moscow proper, and 7.6 in the Moscow region [8].

\subsection{Consequences and costs of wasted time}

2.1 million cars are registered in the Moscow Region, with an average of 300 cars per 1,000 people [8]. By 2015 the number of cars in Moscow is expected to grow to 8 million. Traffic density will grow by $60-70$ percent. Economic losses from traffic jams are projected to reach 450.000 million rubles annually (Speech of the Minister of Transport Igor Levitin at the extended session of the Ministry of Transport board, $30^{\text {th }}$ September 2008). The impact on the Gross Regional Product (GRP) of Moscow and the Moscow region due to the time lost in traffic has reached 400.000 million rubles per year, or 6 percent of the GRP of the Moscow region [8].

The number of traffic jams in Moscow continues to grow. In spring of 2008, about 800 traffic jams were registered daily, up from 750 daily traffic jams between the spring of 2007 and spring of 2008, and 650 during the same period between 2006 and 2007. The average driver was losing 12 hours monthly in traffic jams in spring of 2008 - one and a half hours more than a year before [9].

\subsection{Consequences and costs of pollution}

Motorized transportation is already the main source of air pollution in the Moscow region. Gross output of polluting substances from motorized transportation in the city of Moscow is approximately 1 million tonnes, and in the Moscow region about 2 million tonnes [8].

The annual economic loss from air pollution, noise and climate impact due to motor transport in the Russian Federation has been estimated to reach 2-3 percent of GNP with general ecological losses of 10 percent and expenditures 
(costs) for preservation activities of less than 1 percent. The main share of these losses is due to air pollution by toxic substances (78 percent), which can be explained by the poor quality of Russian gasoline. A further 16 percent of losses is attributable to the negative noise impact of transport on the population [10].

\subsection{Costs of traffic crashes}

The number of accidents has grown continuously. According to official GBDD data (State Inspection of Road Safety Circulation) for 2007, almost 15,000 road crashes were registered in Moscow and 1,161 people killed. In the Moscow region in 2007 more than 14,000 crashes occurred, causing 2,866 deaths [8].

\section{Motorway concessions in Moscow}

The need for infrastructure investment could partially be alleviated through public private partnerships of motorway concessions. In fact, two pilot projects have been recently awarded to build radial motorways from Moscow.

The first consists of the initial segment $(\mathrm{km} 15-\mathrm{km} \mathrm{58})$ of a planned motorway connection between Moscow and St. Petersburg. The road will complement the existing portion of the M-10 road, one of the busiest roads in Russia, and will provide an alternative connection to Sheremetyevo airport and cities close to Moscow. The other project entails the construction of a toll road link between the planned Moscow ring road and the existing motorway to Minsk, the M-1 Federal Road. Both concessions were awarded in 2009. As of late 2009, the consortiums in both projects were trying to achieve financial close.

The agency responsible for tender and award was "Roads of Russia", which depends on the Transport Ministry of the Russian Federation. Due to lack of experience of the in concession projects, this agency solicited the advice of outside experts. They received the assistance of a group of experts from the Polytechnic University of Madrid (Universidad Politécnica de Madrid, UPM). Financing was provided by a program for strengthening institutions sponsored by the Spanish Institute of Foreign Trade (Instituto Español de Comercio Exterior, ICEX). The main points on which the UPM team advised 'Roads of Russia' were the design of the concession formula, the allocation of risks and the selection of award criteria for the tenders.

The tendering process for the two motorway concessions in Moscow demonstrated several important weaknesses of PPP projects in Russia. One of the main difficulties encountered in the preparation of these pilot PPP projects was the lack of expertise to deal with many of the issues involved in the concession tendering process such as selection of award criteria or risks allocation. In addition, the two projects in Moscow also showed the complexity and rigidity of the Russian legal framework for concessions, as well as the weakness of domestic financial markets and the difficulty in mitigating the exchange rate risk. Moreover, the preparation for the bidding process also showed the difficulty in coordinating between the various public agencies involved. 
However, with the final award of the projects, and assuming careful monitoring, the new roads will contribute to reduce traffic congestion in Moscow. Numerous other motorway projects in Moscow could materialize through public private partnerships. Preliminary analyses conducted several years ago showed that it should be possible to build or improve more than 10,000 kilometres of 4 lane motorways in the Russian Federation through PPPs. Among them, close to 2,000 km could be new construction (Eijbergen et al. [5]). The use of concessions in the Russian Federation, however, faces many obstacles. These are analyzed in the following section.

\section{Prospects for further development of PPP road projects in the Russian Federation}

As demonstrated by the two examples of road concession in Moscow, PPPs can be a valuable solution to improve and increase road infrastructure in the Russian Federation. Some factors are crucial, however, in order to enable the further development of motorway concessions in the specific context of this country. This section identifies a list of factors which based on the authors' experience in the Russian Federation, in Central and Eastern Europe, and in several Asian countries, and also draws on findings from recent publications [11-15].

- Capacity of the administration to manage concessions, including tendering, awarding and monitoring of ongoing concessions. It is necessary that the administration have sufficient capacity and knowhow to efficiently manage the concession tenders - including not only technical aspects but also the economic, financial, legal, administrative and business aspects. To this end, it would be very useful to develop more capacity building programs.

- Transparency in the award processes. Increased transparency is needed in the award process in order to ensure competitive bidding.

- Adequate legislation. Land legislation in the Russian Federation presents numerous challenges; in particular, the absence of specific rules governing the reservation and seizure of land, and issues related to the tenure of land upon which transport and infrastructure stands. In order for concessions to be effective, the legislation should be simplified, especially sections dealing with permits and licenses. In addition, legislation on record-keeping and real estate registration should be harmonised with new laws.

- Legal security. Companies must have the guarantee that all concession contracts will be respected throughout the duration of the contract. To this end, contracts should incorporate a clause requiring international arbitration in the case of conflict between the bidder and the administration.

- Size of the domestic financial market. Limited development of the domestic financial market and serious restrictions, particularly in longterm finance, complicate project financing. 
- Stability of the exchange rate. The unpredictability of the exchange rate between the ruble and the Euro and US dollar is an obstacle to raising international funds for infrastructure projects. One potential solution would have the administration provide guarantees regarding the exchange rate, but this could represent a steep cost for the government.

- Willingness to pay for roadway use. Depending on the rate level, a significant part of the population might be discouraged from use of the concession motorways, despite road congestion. In addition, the population is not accustomed to pay for the use of road infrastructure, suggesting that it may take time before it becomes commonly accepted and the advantages are widely understood.

- $\quad$ The need for a robust project portfolio. Projects should be prepared with solid feasibility studies to prove the viability of new concessions: economic and financial analysis, environmental impact etc. Planning the preparation of such studies needs to be part of the project design.

- Public sector coordination. All departments from the different Ministries (Transports, Economics, Finance etc.) involved in the multiple steps of a concession should be coordinated and have a clear definition of their duties and responsibilities in the process. This is necessary in order to ensure a transparent and competitive bidding process completed in a reasonable period of time.

In addition to the factors mentioned, the evolution of PPP projects in the Russian Federation will be severely affected by the worldwide financial crisis. Economic conditions have made it much more difficult to achieve financial close for any PPP project and have strongly increased the requirements demanded by financial entities.

As long as these factors are addressed, concessions can be an effective solution for improving and increasing the stock of road infrastructure in the Russian Federation. Further work is needed to ensure the realization of such favorable conditions, which are crucial in order to attract foreign investment to the country.

\section{References}

[1] Federal State Statistics Service, Transport in Russia 2007.

[2] Federal State Statistics Service, Statistical Yearbook of Russia 2007.

[3] Federal State Statistics Service, Russia in figures 2008.

[4] Filina, V., Competitiveness Problems of the National Transportation System. Studies on Russian Economic Development, 19 (3), pp. 248-261, 2008.

[5] Eijbergen, B., Thompson, L., Carruthers, R., Gwilliam, K. \& Podolske, R., Russia: The Transport Sector, World Bank Policy Note n. 33902, 2004.

[6] Misharin, A., Main projects in developing transport infrastructure, Ministry of Transport of the Russian Federation, 2006. 
[7] ICEX, Infraestructuras de transporte por carretera en la Federación Rusa, Oficina Económica y Comercial de España en Moscú, Instituto Español de Comercio Exterior (ICEX), 2006.

[8] State Commission, The session of the State Commission on providing safety on roads, Moscow 26th October 2008.

[9] Yandex maps, Survey held by the "Yandex" web service, from "Yandex Maps" statistics, summer 2008.

[10] Bajanov, A., Thesis of A.A. Bajanov applying for the candidate of Social Science Degree. Elaborated in the Institute of the Economics of the Russian Academy of Science. Moscow, 2008.

[11] Cuttaree V., Humphreys M., Muzira S. \& Strand J.P., Private Participation in the Transport Sector: Lessons from Recent Experience in the CEE and SEE Countries, World Bank, Transport Paper n. 24, 2009.

[12] Carpintero, S., Toll roads in Central and Eastern Europe: promises and performance. Transport Reviews (forthcoming), 2010.

[13] OECD Transport infrastructure investment: options for efficiency, OECDInternational Transport Forum, 2008.

[14] Carpintero, S., López Corral, A. \& Sánchez Soliño, A., Las concesiones de infraestructuras de transporte en los países del Centro y Este de Europa: influencia del entorno institucional. Revista de Obras Públicas, n. 3492, pp. 7-12, 2008.

[15] Zvorkyna, Y., Public-private partnerships in the transport sector: a Russian view, in Law in transition 2007, European Bank for Reconstruction and Development (EBRD), 2007.

[16] International Transport Forum (OECD), Database available at www.internationaltransportforum.org

[17] López Corral, A., Sánchez Soliño, A. \& Carpintero, S. (2008) Exportación del modelo español de concesiones: el caso de la autopista Moscú-San Petersburgo. Boletín Económico de ICE n. 2935, 23-30. 